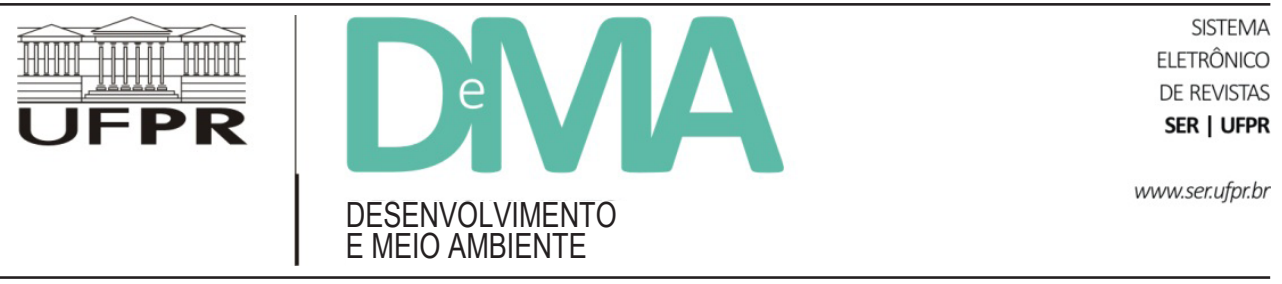

\title{
Political Ecology in Latin America: the Social Re-Appropriation of Nature, the Reinvention of Territories and the Construction of an Environmental Rationality
}

\section{A Ecologia Política na América Latina: a reapropriação da natureza, a reinvenção dos territórios e a construção da racionalidade ambiental}

\section{La Ecología Política en América Latina: la reapropiación de la naturaleza, la reinvención de los territorios y la construcción de la racionalidad ambiental}

\author{
Carlos Walter PORTO-GONÇALVES ${ }^{1}$, Enrique LEFF²* \\ ${ }^{1}$ Universidade Federal Fluminense (UFF), Niterói, RJ, Brasil. \\ ${ }^{2}$ Universidad Nacional Autónoma de México (UNAM), Ciudad de México, México. \\ *E-mail of contact: enrique.leff@yahoo.com
}

Article received in October 16, 2015, final version accepted in November 20, 2015.

ABSTRACT: Political ecology is the disciplinary and political field regarding the encountering of different rationalities for the social appropriation of nature and the construction of a sustainable future. This historical purpose demands the deconstruction of theories and practices built on the foundations of scientific, economic, technological and political modern rationality, inscribed in national and international institutions of the globalized world and rooted in the life-worlds of the people, to establish new socio-environmental relations. Political ecology operates this deconstruction not only in theory, but through emancipation practices of those people engaged in struggles for the reinvention of their identities and the re-appropriation of their bio-cultural territories. Environmental rationality deconstructs the economic rationality by constructing an eco-technological-cultural paradigm of production founded on the principle of negentropic productivity. The conditions of life of diverse cultures, registered on people's imaginaries and practices, reemerge today in the re-signification and re-affirmation of cultural identities in their struggles for the re-appropriation of nature and re-territorialization of their life-worlds.

Keywords: political ecology; Latin America; social appropriation of nature; territory; sustainability; environmental rationality.

RESUMO: A ecologia política é o campo disciplinar e político do encontro de diferentes racionalidades na apropriação social da natureza e na construção de um futuro sustentável. Este propósito histórico demanda a desconstrução 
das teorias e práticas edificadas sobre os fundamentos da racionalidade científica, econômica, tecnológica e política da modernidade, inscritas nas instituições nacionais e internacionais do mundo globalizado e arraigadas nos mundos de vida das pessoas, para construir novas relações socioambientais. A ecologia política não só opera esta desconstrução na teoria, mas também por meio das práticas de emancipação dos povos nas suas lutas pela reinvenção de suas identidades e pela reapropriação de seus territórios bioculturais. A racionalidade ambiental desconstrói a racionalidade econômica dominante por meio da construção de um paradigma eco-tecnológico-cultural de produção fundado no princípio da produtividade neguentrópica. As condições de vida das diferentes culturas, registradas nos imaginários e práticas dos povos, reemergem hoje na ressignificação e na reafirmação de suas identidades culturais, em suas lutas pela reapropriação da natureza e pela reterritorialização de seus mundos de vida.

Palavras-chave: ecologia política; América Latina; apropriação social da natureza; território; sustentabilidade; racionalidade ambiental.

RESUMEN: La ecología política es el campo disciplinario y político del encuentro de diferentes racionalidades, en la apropiación social de la naturaleza y en la construcción de un futuro sustentable. Este propósito histórico demanda la deconstrucción de las teorías y prácticas edificadas sobre los fundamentos de la racionalidad científica, económica tecnológica y política de la modernidad, inscritas en las instituciones nacionales e internacionales del mundo globalizado y arraigadas en los mundos de vida de la gente, para construir nuevas relaciones socio-ambientales. La ecología política no sólo opera esta deconstrucción en la teoría, sino a través de prácticas de emancipación de los pueblos en sus luchas por la reinvención de sus identidades y la reapropiación de sus territorios bio-culturales. La racionalidad ambiental deconstruye la racionalidad económica dominante a través de la construcción de un paradigma eco-tecnológico-cultural de producción fundado en el principio de productividad negentrópica. Las condiciones de vida de las diferentes culturas, registradas en los imaginarios y prácticas de los pueblos, reemergen hoy en la re-significación y re-afirmación de sus identidades culturales, en sus luchas por la reapropiación de la naturaleza y la re-territorialización de sus mundos de vida.

Palabras clave: ecología política; América Latina; apropiación social de la naturaleza; territorio; sustentabilidad; racionalidad ambiental.

\section{Emergence of the environmental crisis: the political-epistemic debate}

The environmental problems irrupted in the $60 \mathrm{~s}$ represent a crisis of civilization: a limit in the progression of modernity and the opening of new civilization horizons in the perspective of sustainability. This divergence in the course of history called for the merging of nature and culture that was divided by the ontological and epistemological dualism that founded modernity. The environmental question arose along with other social issues, public debates and emancipation processes: the feminist, gender and students movements; the ethnic-racial question that gained prominence with the decolonization of Asian and African people, as well as the black movement in the USA.

The ecological movement emerged in this context discussing the environmental crisis triggered by economic growth and technological progress: from the critique of the arms race to the "society of waste and pollution" brought about by industrialization. New epistemic horizons were opened from the standpoint of the sciences and methods of complexity, post-structuralism and the philosophy of post-modernity. Hermeneutics, deconstructionism and constructivism were associated with the search of new ways of thinking and constructing knowledge that oriented emancipation processes from oppressive social structures and an objectified reality: from patriarchy and gerontocracy, capitalism and socialism, scientism and technology.

From then on, the idea of the limits to human intervention in nature gained force. After the atomic bomb in Hiroshima and Nagasaki, science lost its neutral status, questioning its effects on society. Science was not necessarily at the service of life or human emancipation as pretended by the Enlightenment. The crisis of science did 
not arise primarily from its internal theoretical inquiries, but from damages derived from its applications. The repercussions in society of scientific rationality implied the critique of its metaphysical-ontological-epistemological foundations, mainly of its hegemonic positivist and structural-functionalist derivations, and by questioning the power strategies embedded in knowledge (Foucault, 1980). This crisis of scientific reason opened ways for other epistemological approaches to emerge as well as other rationality matrixes, including the emancipation of subjugated knowledge by the epistemological colonialism of Eurocentric thinking which ignored and disqualified other cultural worldviews, other human experiences and practices, other forms of cognition and knowledge.

From Vance Packard's The Waste Makers (1960), to Rachel Carson's Silent Spring (1962), Paul Erlich's The Population Bomb (1968), Nicholas GeorgescuRoegen's The Economic Process and the Entropy Law (1971), the MIT/Club of Rome study on The Limits to Growth (Meadows et al., 1972), Hans Magnus Enzensberger's Critique of political ecology (1974), and Celso Furtado's O Mito do Desenvolvimento ("The Myth of Development") (1974), the environmental debate acquired explicit political dimensions. It is in this intellectual context that the United Nations convened the first World Conference on Human Environment, held in Stockholm, in 1972. Thus, the environmental question entered the international geopolitical agenda.

The environmental crisis came to question the civilizatory project based on the anthropocentric ideal of man's domination of nature instituted in the rationality of modernity, where its ethic, epistemic, technical and political dimensions conflate in the centrality of economic rationality in social life (Leff, 2004). The separation between human and natural sciences, beyond the specialization within each one of these fields, corresponds to the separation of peasants and natives from nature, banishing communities from their territories. The search for basic essential unities of different ontological order became an epistemic obsession of modern science: in biology, with the cell or the molecule; in physics with the atom; with the individual in the social sciences. The belief in the scientific world that the mysteries of nature are revealed in mathematical language was to be reflected in the mundane world in the unitary logic of market values. Thus, the hegemonic paradigms of modernity were instituted on the individuals' lives.

With the environmental crisis, the inquiry on nature became an epistemological and a political debate on the sustainability of life. Nature was subdued to modern scientific and technological development, particularly after economic rationality was instituted as the reason-of-being-in-the-world and individual behaviors conducted by rational choice. With the capitalist mode of production, modern economy abandoned the Physiocratic principle which affirmed that nature was the source of wealth through the reproduction of seeds. With this oblivion of nature, economic rationality externalized nature and abandoned the inquiry on the ecological conditions for the sustainability of the economic process. The economic process became an increasing process of production mobilized by fossil fuels (carbon and oil) that slowly but irreversibly and in complex ways generated ecological decay and the environmental planet's degradation .

To be sure, the economy cannot produce nature: energy contained in a molecule of carbon or in the atom, even if put into production by modern economy, was not produced by humans; no country, no society, no people have produced iron, oil or water. However, the degradation of matter and energy into soil, water and air pollution is produced by the economic process and considered "externalities" of the economic system. Thus, the environmental crisis came to question economic rationality: the epistemological conception of ideas (res cogitans) outside nature (res extensa).

With the environmental crisis, sustainability has emerged as a condition and a goal for global ecological balance and human survival. However, sustainability is a polysemic concept that cannot be universally and unanimously defined. The dispute of meanings and strategies for the social construction of a sustainable future is at the very center of political ecology. Within the diverse approaches to sustainability in environmental and ecological economics, two radically different approaches are distinguished within political ecology: one being configured under the hegemonic economic rationality; the other based on ecological potentials and cultural identities in the construction of an alternative environmental rationality (Leff, 2004), based on cultural diversity, the reinvention of territories and the social appropriation of 
nature. People's emancipation strategies for sustainability are thus distinguished from the dominant geopolitics of a sustainable development.

\section{The geopolitics of sustainable development}

Political ecology is the disciplinary and the political field of encountering of different rationalities in the social appropriation of nature and for the construction of a sustainable future. This historical objective demands the deconstruction of theories and practices built on the foundations of scientific, economic, technological and political rationality, inscribed in national and international institutions and rooted in the majority of the peoples' life-worlds, to establish new socio-environmental relations. This deconstruction is not only operated by political ecology as theory, but above all by emancipation practices of those peoples engaged in struggles for the re-appropriation of nature (Leff, 2004) and the reinvention of their territorialities (Porto-Gonçalves, 2006).

In this sense, political ecology transcends the purpose to ecologizing the economy by assigning market values to nature and economic instruments to environmental management (Polanyi, 1980; Martínez Alier, 1996; Leff, 2004; Bartra, 2008). Beyond the debates between "fictitious economy" and "real economy", between "speculative capital" and "productive capital", political ecology recaptures the economy based on the productive processes of nature, its cultural meanings and its territorial inscription. As pointed out by ecological economics, the economy should be understood and treated as a subsystem of a larger finite system, the biosphere, which implies the impossibility of permanent growth. The established economy generates distributive inequalities in economic wealth, ecological potentialities and environmental costs, questioning the belief in the regulative mechanisms of the economy, the power of techno-science and the fallacy of its capacity to dematerialize production:

the difference in emissions of greenhouse gases between individuals, based on their economic wealth and consumption patterns [...] shows that the 500 million richest people of the world ( $7 \%$ of world population) generate half of the greenhouse gases dumped to the atmosphere [...] Even though today one unit of monetary value might be produced with $30 \%$ less materials than 30 years ago, there was an increase of $50 \%$ in the demand of these materials in the same period. Considering that the average consumption of natural resources by the American people is 88 kilograms per day, and that of the African people of south Sahara is only 10 kilograms daily (Friends of Earth et al., 2009), a generalization of consumption patterns to those of the richest countries would lead to an increase of the pressure over the sustainability of ecosystems and their capacity to offer the basic environmental services. It is a false illusion to think that the reduction of present social inequalities can be compatible with the generalization of the consumption patterns of that $7 \%$ of the world population that is responsible for half of the emissions of greenhouse effect gases (Abramovay, 2010).

After the Stockholm Conference in 1972 a worldwide debate on the limits of the present trends of human intervention on nature was launched; ecological movements oriented the debate on the economic and political interests involved in the social appropriation of nature. Nature was re-signified by the transformations of social and power relations induced by a new cycle of economic growth and technological development through biotechnology, genetic engineering, microelectronics, informatics, nanotechnology and robotics (Porto-Gonçalves, 2006). Biodiversity and germplasm became sources of capital accumulation for transnational corporations through new strategies for the appropriation of nature, such as etno-bio-piracy and the attempt to legitimize intellectual property rights over natural processes. The principle of private property was extended not only to plants and animals, but to microscopic cells and the nanoscopic levels of genes. While until then all cultures had established their relations with nature at a macroscopic level of the organism, nanotechnology expands the frontier of capital to the interior of matter and of the living cell. The gene is only observable and modified with instruments of microscopic research. Thus, the locus for the production of knowledge and meaning of nature shifted from the life-worlds and livelihoods of the people to the laboratories of biotechnology as centers of bio-power for the expansion of capital 
(Porto-Gonçalves, 2007). At another level, the increasing emission of greenhouse effect gases resulting from the industrial metabolism mobilized by fossil fuels that has transformed the composition of the atmosphere, generated complex meteorological processes and triggered climate change. Their regulation has entered the financial circuits with the pretension of protecting the environment through the economic coding and valuing of carbon bonds as the basis for negotiations of global warming (Cornetta, 2010).

The scientific controversies on biodiversity and climate change have been trapped in the power strategies of sustainable development (Leff, 2002; Porto-Gonçalves, 2006; Bartra, 2008). The environmental question has been captured by the logics of the market and its financial strategies, as well as by normal science, ignoring the power relations that cut across the geopolitics of biodiversity and sustainable development that extends, intensifies and complexifies previous processes of destructive appropriation of natural resources. The geopolitics of sustainable development is configured in the context of economic globalization. Thus, together with the historical forms of nature exploitation that characterized the "pillage of the Third World" (Jalée 1968), global capital promotes today a "conservationist" exploitation of nature. Biodiversity appears not only as a multiplicity of live forms, but as natural reserves -habitat of biological and cultural diversity-, valued for their genetic wealth, as eco-touristic resources or for its function in collecting carbon. If in modern-colonial times, sugar cane, cotton, banana or coffee monocultures were established in Latin America, the economic value of biodiversity is leading to a new type of landlordism: conservation areas and genetic latifundia (Porto-Gonçalves, 2002). Large areas are being transformed into conservation units or converted to modified genetic crops, ignoring that those territories which remained at the margins of the market are the areas harboring the greatest natural wealth in water and biodiversity of the planet, having been historically inhabited by traditional populations -indigenous, peasant and maroon people-, who have preserved these territories as a natural and cultural patrimony.

Political ecology becomes the field where the controversies between the economization of nature and the ecologization of the economy are deployed, where different, and often opposing, strategies for the appropriation of nature are confronted and collide. The discourse of sustainable development is a strategy for the economic appropriation of nature that "denaturalizes" it through technology, inducing a process of transgenesis that invades and transmutes life, searching to normalize and to legitimize the merchandizing of nature.

The merchandizing of nature deepens the differences between rich and poor countries under the principles of sustainable development. Economic-ecologic globalization justifies the comparative advantage between the more industrialized and pollutant countries and the poor countries that are being induced to value economically their capacities to capture the excess of carbon dioxide and other greenhouse effect gases dumped to the atmosphere by the rich countries and to offer the genetic resources from their reserves of biodiversity. The differences between central and peripheral countries are not only produced by the pillage and overexploitation of their resources, but are now being masked by new functions assigned to their territories through economic strategies for the appropriation of environmental goods and services. This is no longer a race for development based on comparative advantages in the endowment and accumulation of productive factors, with the purpose of breaching the technological gap and attaining a more equitable world. Rather than valuing biodiversity as a potential for alternative development, it is reduced to a means to mitigate the increasing ecological footprint of the developed countries and to continue extracting the materials needed for their unsustainable growth -oil, minerals, cellulose and foodstuff- as well as for the capital accumulation of the emergent economies of countries like China, India and Brazil.

For some governments and authors, this exchange of nature for technology represents a win-win strategy, both in economic terms and for ecological conservation. That is the fallacy promoted by the power devices and discursive strategies of the geopolitics of "sustainable development", such as the "Programme for Reducing Emissions from Deforestation and Forest Degradation" (REDD), the "Green Economy" and the "Clean Development Mechanism" (CDM). The REDD Programme, together with other instruments for "sustainable development" pretends to reduce the negative contribution from 
deforestation and forest degradation to greenhouse effect emissions. Actually, it intends to re-functionalize the integration of the Third World territories in the global economy, to sustain the unsustainable growth of the more developed economies, unable to "dematerialize" their economies and to restrain their increasing emissions and ecological footprint through "green" technologies. Thus, the CDM pretends to preserve biodiversity, while actually inducing artificial forest plantations to increase the capacity to capture the excess emissions of industrialized countries and to produce natural commodities, such as cellulose and other forest goods, as well as developing new products derived from biodiversity.

In this sense, an economic role is assigned to forests and biodiversity for their capacity to capture carbon and to balance the emissions of greenhouse effect gases in the purpose to mitigate global warming. This redefinition of unequal exchange in the integration of third world countries and tropical regions to the global economy functions as a subvention to continuous unsustainable economic growth, offering limited and dubious benefits to tropical countries and to the overall sustainability of the planet. In exchange for the artificiality of ecosystems in the North, to the unstoppable progress of industry and a highly capitalized and technologized agriculture, some exceptional territories are granted the luxury of maintaining a "natural economy", to continue living out of the generosity of Mother Earth by valuing the comparative advantages offered to them by the geographic localization of their territories.

This imposed role on nature and culture by the geopolitics of sustainable development implies, over the purpose of reducing emissions, a reduction of the natural and cultural potentials for the construction of alternative sustainable economies and of other possible worlds. In this sense, the indigenous peoples represented in the First International Forum of Indigenous Peoples on Climate Change, held in Lyon, France in September 2000 , rejected the inclusion of carbon sinks under the CDM because

it reduces our sacred land and territories to mere carbon sequestration which is contrary to our worldviews and philosophy of life. Sinks in the CDM would constitute a worldwide strategy for expropriating our lands and ter- ritories and violating our fundamental rights that would culminate in a new form of colonialism. Sinks in the CDM would not help to reduce GHG emissions; rather it would provide industrialized countries with a ploy to avoid reducing their emissions at source [...] the CDM pose the threat of invasion and loss of our land and territories by establishing new regimes for protected areas and privatization. We emphatically oppose the inclusion of sinks, plantations, nuclear power, mega-hydroelectric and coal. Furthermore, we oppose the development of a carbon market that would broaden the scope of globalization (International Indian Treaty Council, 2000).

Contesting the capitalistic strategies for the appropriation of nature, traditional peoples are developing new strategies to re-appropriate their natural and cultural patrimony, to reinvent their modes of production and ways of inhabiting their life territories. Thus, the seringueiro Chico Mendes (1944-1988) became the leader of a new peasant's socio-environmental movement, fighting against the hegemonic economic rationality for the exploitation of nature. He proposed the extractive reserves as a new "agrarian reform", countering the strategies of "sustainable development" and the implantation of genetic latifundia (Porto-Gonçalves, 2002; 2004). Facing the colonizing and exploitative character of the new geopolitics of globalization and sustainable development, in the conflictive field of political ecology different critical and creative responses are emerging from Latin American peoples.

\section{Political ecology in Latin America: thinkers and actors}

After the 70s, and throughout a period in which the modern-colonial-world-system was shaken by the environmental crisis, an innovative contribution to environmental thinking and political ecology is emerging from the South, in particular in Latin America. From the first ecological debates, the critique to the society of waste and pollution, of consumerism and productivism has been considered from the concern for the countries and Latin American peoples living under poverty and hunger, unable to consume the minimum necessary to sustain their existence. The debate over nature was mobilized 
by authors like Josué de Castro with his seminal lecture on "Underdevelopment: the primal cause of pollution", presented at the Conference on Human Environment held in Stockholm in 1972, underlining the social causes of environmental unsustainability (de Castro, 2003); or by Celso Furtado (1974), who questioned the idea of development after having been one of its main defendants

Even though orthodox currents of Marxism were at first critical to the emergent ecologism, soon after, some political thinkers and different social movements in Latin America and in the Third World started assimilating the environmental question in their inquiries and political agendas. New theoretical-political currents were developed in the incipient field of political ecology to render account of an emergent "popular ecology", "eco-pedagogy of liberation" and "eco-socialism". The contributions to political ecology in the last 30-40 years are as important today to understand the complex socioenvironmental processes underway, as were at their time the theses of José Carlos Mariategui (1971) for the decolonization of indigenous peoples and of Aimé Césaire (1955), who together with Franz Fanon (2004) founded the "négritude" movement; or the Theory of Dependence and Internal Colonialism in the 60s-70s, with authors like Ruy Mauro Marini, Theotonio dos Santos, André Gunder-Frank and Pablo González Casanova (1965) (among others), and the Theology of Liberation and the Pedagogy of the Oppressed of Paulo Freire (Marini \& dos Santos, 1999); and more recently, the inquiries on Decolonial Thinking and Coloniality of Knowledge of Aníbal Quijano, Enrique Dussel, Walter Mignolo, Arturo Escobar, Catherine Walsh, Ramon Grosfogel, Edgardo Lander and the Aymara-Bolivian sociologist Silvia Rivera Cusicanqui, among other intellectuals and scholars, to understand the historic-socio-political condition of the Latin American people (Lander, 2000; Mignolo, 2011).

A rich diversity of peoples/cultures and their different territorialities made visible a new theoretical perspective of historical time and space as the manifestation of an "unequal accumulation of times" (Santos, 1996), abandoning the linear perspective characteristic of the Eurocentric conception of time. This conception has important political implications for social movements, such as the actuality of ancestry invoked by the afro-Colombians of the South Pacific and the Andean peoples; the reversal of internal colonialism through the political reinvention of pluri-nationality, the co-evolution of peoples/cultures and nature/territories and the social imaginaries of sustainability (Leff, 2010).

John Murra (1956) elaborated a rich analysis of the organization of the geographical space of the natives of Tawantinsuyu (Quechuas and Aimaras, among others) where the Andean ecological floors were articulated from the West Pacific coast to the Chaco-Pantanal region, and interlinked to the Central Brazilian Plateau to the East. Different from the territorial division of labor and space imposed by the capitalist agriculture, the principles of complementariness and reciprocity commanded the organization of geographical space in their productive practices. These conceptions of the cultural occupation of space are being re-evaluated by emergent theoreticalpolitical approaches of original peoples' movements to re-appropriate their ancestral territories (Tapia, 2009).

The cultural territories of Latin America are a patrimony derived from the legacy of their rich and diverse cultures, of their original and traditional knowledge that goes back to the ancestral forms of occupation of the continent and to the formation of its climatic and botanical domains housed in the natural heritage of tropical forests, savannas, steppes, punas, moorlands, mangroves and wetlands; that is, of the wealth of biological diversity of the continent (Ab'Saber, 1977). The original populations that inhabited these areas co-evolved with the ecosystem dynamics of their territories developing a rich collection of knowledge that, together with their biological diversity, represents a historic patrimony of the cultures that inhabit those territories, constructed mostly in relation with, and not against nature. This diversified patrimony of knowledge of indigenous peoples, peasants and maroons, subjugated by colonial and capitalist domination, encounters today scientific knowledge that supports the techno-economic appropriation of nature.

Traditional knowledge is often referred to as "local knowledge", "popular wisdom"or "folk science"; as "indigenous science" (De Gortari, 1963), "macro-systems" (López-Luján \& López-Austin, 1996), "native sciences" (Cardona, 1986), “popular knowledge or people's science" (Fals Borda, 1981; 1987). In English literature they are named traditional, non-western, or traditional ecological knowledge. In general terms, these sets of 
practical, experimental and reflexive knowledge represent a cultural patrimony transmitted from generation to generation. These "systems of indigenous knowledge" (Argueta \& Vásquez, 1994), are embodied in practices for the sustainability of life, such as food production and health care; they are embedded in their territories conceived as spaces where identities are forged and renewed. These cultural identities include language and communication systems; history and collective memory; norms for conviviality among parents and neighbors; relations with other peoples and societies that are expressed in common customs and law (Thompson, 1991); myths and rituals, religion and festivities where the transcendental lives of the peoples are expressed.

\section{Territories, territorialities and territorialization}

The inscription of the Latin American and Caribbean peoples in the globalized world in the recent period of neoliberal hegemony triggered a theoretical-political debate in the environmental field where the concept of territory and its correlates, territoriality and territorialization, have been highlighted (Porto-Gonçalves, 2001; Haesbaert, 2011). From Barbados Declaration (1971) to the Convention 169 of International labor Organization (1989) and UN Declaration of the Rights of Indigenous Peoples (2007), the territorial rights of natives, peasants and afro-Americans were forged, recognizing other forms of living, appropriation of space and inhabiting the world. The historical struggles of these peoples and ethnic groups are configuring a new geopolitics drawn for/against the neoliberal policies after the 90s, when important political reforms in different countries - especially in their national constitutions and legislative bodies - , recognized the rights of natives, peasants and maroon populations to their environments. These democratic changes triggered processes of cultural emancipation of traditional peoples for the re-appropriation of their ancestral territories, encountering the interests and reaction of dominant social groups. Territorial struggles are becoming an outstanding issue of political ecology in Latin America, revealing the conflicts between the National State, the domineering economic and political power groups with the new territorialities arising from cultural re-appropriation of nature in the perspective of an environmental rationality.

The rights to difference derived from postmodern philosophy reflected in a new politics of identity. Beyond its eagerness to deconstruct social theories and practices centered on class struggles, the politics of difference renewed the Latin American debates on the class/ethnic imbrications pointed out since 1920 by José Carlos Mariátegui (1971), and more recently the race/ class distinction developed by Aníbal Quijano (2000). The theoretical debate on the politics of difference gives ground to emergent juridical-political procedures and to new forms of territorialization of indigenous peoples and rural populations.

The "territorial question" is being debated and inscribed in a tense political process as the confrontation of power strategies for the appropriation of nature. Two combined processes of expropriation occurred in the constitution of the colonial-modern world system: 1. The conquest/invasion of Abya Yala/América, that from its very start generated a territorial tension with the deterritorialization of African peoples via the traffic of slaves and the colonization of Latin America natives; 2 . The "enclosure" of the communal lands of the peasantry in Europe during the 17th and 18th centuries to establish private property for capitalist agriculture. Peasant's property forms traditionally were family based under communal use of land, forests and water resources. This is the case of traditional peasant forms of property in different Third World regions, such as the ayllus quéchua/aymara; the Russian mir (Zasulich/Marx); the Mexican ejidos with their milpas and family orchards; the territoriality of seringueiros in the Brazilian Amazon (Porto-Gonçalves, 2004), the retireiros of Araguaia river and their varjões (common lands); the faxinais in South Brazil or the fundos de pasto (pasture lands) in the North-east of Brazil (Campos, 2000).

Nature and culture that had been politicized by the agrarian revolutions in the 20th century for the social distribution of land, acquired new meanings with the shift from the struggle for land to the claim for territory, confronting the National State as a territory inhabited by multiple territorialities. The struggle over territories involves a theoretical-political debate, as assumed by 
indigenous leaders, such as the Quéchua-Ecuatorian agronomist Luis Macas, ex-president of the Coordination of Indigenous Nationalities of Ecuador - CONAIE when he states: "our struggle is epistemic and political".

The concept of territory no longer designates the physical-geographical base for the exercise of State's sovereignty as consecrated by international law and political science, shifting to a process of appropriation and control of geographical space, of its peoples and resources, revealing the power relations that traverse the field of political ecology. The territory is being "reinvented" as a space-place for the cultural re-appropriation of nature (Porto-Gonçalves, 2004; Raffestin, 1980; Haesbaert, 2011; Sack, 1985; Harvey, 2003). At the basis of this conceptual change are the struggles of peasants, indigenous peoples and maroons. Political ecology is thus conceptually constituted and deployed in practice by politics of difference within the triad territory-territoriality-territorialization.

As cultural rights guide these processes of reterritorialization, the material/symbolic appropriation of nature involves a dispute over the meanings assigned to nature within the cosmogonies and socio-economic practices of cultural organizations. Thus, nature and culture are politicized. The territory is redefined as the summa of nature/culture power relations. This is one of the identity traits of Latin American political ecology.

The condition for the reproduction of capitalist production relations is the permanent separation of peoples and ethnic groups from their material/natural conditions of existence with the destruction of community modes of production and world lives, with individualized men and women in one side, and nature without people in the other, converted into mere forces of production and commodities. The environment, reduced to a generic nature-society relation under the geopolitics of sustainable development, appears as a political ecological question: the social re-appropriation of nature (Leff, 2004).

By the end of the 80s and through the 90s, the environmental question acquired new political projection with the emergence of new cultural-environmental peasant and indigenous movements, as that of Seringueiros in the Brazilian Amazonia, the afro-Colombians from the tropical forests of Colombian South Pacific and the Zapatista indigenous movement in Mexico. The sandinista-miskitos affair in Nicaragua in 1979-1989 played an important role in this breakthrough, when the Miskito indigenous people opposed the Marxist Sandinista vision of progress guided by the development of productive forces, confronting the hegemonic vision within the left. A similar conflict has irrupted recently in Bolivia with the indigenous people that claim their rights to their biodiverse ecological territory (TIPNIS) while the government intends to construct a road across the reserve to promote the economic development of the region.

\section{The reinvention of other territorialized rationalities}

The re-signification of nature after the 60 s involved new protagonists in the field of political ecology, peoples whose culture is interwoven with nature in the territories they inhabit: indigenous peoples, afro-Americans, peasants, riverside dwellers. New collective identities have been emerging from different ethnic conditions and cultural relations with nature, involving different social practices and modes of being of rural dwellers: seringueiros, castanheiros, fishermen, babassu coconut breaker women.

These social actors emerge from their resistance to being absorbed (de-territorialized) by globalization and their claims to redefine their environments and their cultural identities in order to build their sustainable worlds. In this perspective, these resistance processes turn to be movements of $r$-existence. These populations do not only resist against dispossession and de-territorialization: they redefine their forms of existence through emancipation movements, by reinventing their identities, their ways of thinking, their modes of production and their livelihoods. After 500 years of modern colonization of Latin America and the Caribbean, in spite of the oppression to which they were submitted, these populations have not only persisted: they have reaffirmed themselves by reinventing their cultural beings. By claiming their rights to their territory, indigenous peoples are revaluing the ecological-cultural space that they inhabit, territorializing their productive and social practices. 
An analysis of the different morfo-climatic domains of the Latin American landscapes reveals that in those regions, still covered by dense tropical forests - like the Amazon region with its eight million square kilometers, as well as the large areas of the Atlantic Forest, that covers almost the totality of the Atlantic Brazilian Coast-, there was previously no forest but herbaceous and shrub vegetation, known in Brazil as cerrados and caatinga. In these areas, the dominant weather 18,000 and 12,000 years ago, was much dryer and thus limited the formation of dense forests that were restricted to some niches and refuges (Ab'Saber, 1970). Original peoples like the Tupi, the Guarani and the Aruaque, among others, inhabited these ecosystems co-evolving with nature (Posey, 2004).

In the mountain region of the Tehuantepec Isthmus in Southern Mexico, within the states of Chiapas, Oaxaca and Veracruz, the territories of Uxpanapa and Chimalapas represent areas particularly rich in biodiversity within the complex and dynamic refuges of flora characteristic of this region. Inventories of biodiversity of the tropical forest of Uxpanapa identified 924 plants, 150 poultry, 34 mammals, seven turtles and 13 fish species in three ecosystems. Only in one ejido, that of Agustín Melgar in Uxpanapa, 168 useful species were recognized in the primary forest; 155 in the secondary forest and 33 in rivers, totaling 356 useful species for foodstuff, medical remedies, construction materials, woods, forages, skins, fibers, gums, waxes, poisons, dyes and flavoring substances. The biodiversity being appropriated by indigenous communities in their growing areas and family orchards adds to 783 identified useful species (Toledo et al., 1978).

Central America and the Amazon are two of the most extended biodiverse areas of the planet. The Amazon forest covering areas of Brazil, Colombia, Peru, Ecuador, Bolivia, Venezuela, Surinam, Guyana and French Guyana, adding up to a continuous extension of eight million square kilometers of tropical forest that contains between 500 and 700 tons of biomass per hectare. This mega-ecosystem is an immense "green ocean" responsible for the evapo-transpiration of water that maintains a dynamic equilibrium of the planet's hydrology, an environmental service for the benefit of humanity (Uhl et al., 1991).
These regions contain a rich patrimony of biological diversity, of territories and landscapes interwoven with the different peoples that have inhabited them through history in the co-evolution of culture with nature. These peoples hold an enormous legacy of knowledge welded in their traditional practices for living sustainably within their ecological conditions. Many of the principal crops that feed humanity were domesticated by Amerindian peoples: potato (Solanum tuberosum), original from Peru, of which more than 7,000 cultivars are known; sweet potato (Ipomoea batatas); bitter cassava (Manihot esculenta) and sweet cassava (Manihot dulcis); maize (Zea mays), worldwide base for human and animal nourishment; tomato (Lycopersicum esculentum); beans and peanuts (Arachis hypogaea); fruits as cacao (Theobroma cacao), pineapple (Ananas sativus), caju or cashew nut (Anacardium occidentale), papaya (Carica papaya), íngas (Inga spp.), almonds like the Pará chestnut (Bertholletia excelsa); stimulating plants like guaraná (Paullinia cupana), mate herb (Ilex paraguariensis) and tobacco (Nicotiana tabacum); medicinal plants like ipecacuana (Cephalis ipecacuanha) from where emetine hydrocloride is extracted; copaiba (Copaifera) used against urinary tract disorders; quinine (Cinchona officinale), used against malaria; plants for industrial uses as rubber (Hevea brasiliensis), that has not been totally substituted by synthetic rubber in chirurgical gloves and high quality preservatives, for example; carnauba plant (Copernicia sp.) from where wax is extracted; timbó (Theprosia sp.) that contains a DDT ingredient -rotenone- used as insecticide in sanitary medicine and agriculture; as well as other plants, wild or cultivated, used by indigenous peoples as different kinds of corron (Gossypium spp.); carúa (Neoglaziovia varietata) a kind of bromeliad used to make yarn and fabric, and piaçaba (Leopoldinia piasaba) used as brooms, mats and baskets (Ribeiro, 1992).

Throughout their long history of coexistence and co-evolution within their complex ecosystems, indigenous peoples have developed a complex knowledge on the ecology of these species derived from cultural modes of material and symbolic appropriation of nature within their own cosmogonies and rationalities. This knowledge is embodied in their productive practices and embedded in their territories. The historic-cultural transformations 
underway are the result of the struggles of these indigenous peoples to defend their collective rights to preserve their cultural ways for reconstructing their territorialities, facing the domineering strategies for the appropriation of nature geared by techno-economic rationality and the geopolitics of sustainable development.

\section{The R-existence of indigenous peoples: tradition and modernity}

In the aftermath of the environmental crisis, nature is being revalued because of its regulatory ecological functions to mitigate climate change and for its economic potentials. The preservation of biodiversity emerges as a priority in the strategies of sustainable development not only for its intrinsic value, but as carbon sinks and biotechnological potential. The greatest wealth of biodiversity in the planet is found in the regions inhabited by indigenous and peasant peoples that in recent years are reemerging in the political arena claiming their cultural rights for the re-appropriation of their patrimony of natural resources. Following their historical resistance to modern colonization, new perspectives of emancipation and for the construction of sustainability are emerging derived from their confrontation with the strategies for the appropriation/transformation of nature opened by the expansion of the global economy revitalized by the biotechnological revolution and its counterpart: the legitimization of indigenous peoples' rights to their ancestral territories. The emergent geopolitics of biodiversity conservation and sustainable development deploys its power strategies in the field of political ecology confronted by the indigenous and peasant peoples' cultural rights. What is at stake in these conflicts derived from the clash of alternative paths towards sustainability is not the distribution of benefits from the techno-economic re-appropriation of nature, but rather the r-existence of these traditional populations which is at the bottom of the socio-environmental movements in the South and in Latin America.

\subsection{The R-existence of ecosystem 's peoples: the case of the Seringueiros}

Seringueiros are the self-identified inhabitants of the rich ecosystems in the Brazilian Amazon region. These people, attracted by the rubber fever of the second half of the XIX century from different parts of Brazil, underwent a long struggle over the XX century to settle definitively in those territories, to re-appropriate its natural resources and to reinvent their identities. At first they were prevented by their patrões to practice subsistence agriculture forcing them to dedicate all their labor time to the extraction of latex. Thus, they remained dependent from the owners of the rubber forests, the seringals. The rubber cycle was dependent on this double flux of labor that provided food to the seringals for the production of marketable rubber. Only after the crisis in the rubber market in the second decade of the 20th century, the owners were forced to allow them to practice communal agriculture in order to maintain the seringueiro in the forest. That was the source of the rich experience of these populations combining agriculture and extractive activities.

The seringueiros emerged in the political scene in the State of Acre, in the South-West of the Brazilian Amazon region in the 70s. Their first actions of resistance were to prevent the landowners from felling the forest to plant grass. Under the political direction of the National Confederation of Agricultural Workers (CONTAG), they considered themselves posseiros, squatters having possession of their common land for the extraction of rubber. By the early 80 s the seringueiros had exchanged their old subsistence family parcels (colocaçoes) for individual land plots. From then on, and under the political leadership of the Union of Rural Workers of Xapuri and of Chico Mendes, and in opposition to the CONTAG in Acre, the seringueiros started elaborating an original political proposal that combined their claim for land with the defense of their livelihood. It was the struggle to establish seringueiro territories.

The seringueiros founded in 1985 the National Council of Seringueiros (CNS) which maintains a basic political link with the Union of Rural Workers to avoid their decoupling from their social and territorial base 
while broadening their struggle for land to the defense of the living forests and their life styles. Their proposal to establish Extractive Reserves is the crowning of their seringueiro identity. This conservationist-productive strategy has become a living laboratory in the search of alternative sustainable strategies based on savoirs embodied in their cultural practices and knitted in their territories by their coexistence with the tropical forest. Behind the concept of Extractive Reserves was the idea of the Indigenous Reserves that established the first State guardianship over these communities and their different cultural traits. In the Extractive Reserves, communal land is the property of the Union with usufruct rights by families through their organized entities - unions, cooperatives, neighborhood associations - that elaborated the management plan. The Extractive Reserves combine the usufruct of each family with the communal property under governmental guardianship to guarantee the sustainable use of natural resources while offering institutional conditions to transit towards a self-managed society.

Through the leadership of Chico Mendes, the Seringueiros extended their influence by creating the Alliance of Peoples of the Forest and are settled in 4 million hectares of land decreed as Extractive Reserves, diversifying the production and trade of the forest products and establishing cooperatives to defend their prices against the unequal exchange of their products. They have thus implemented a sustainable productive strategy. Their productive practices are founded in principles of sustainable eco-technological-cultural productivity and environmental rationality (Leff, 1995). They take advantage of the enormous capacity of the Amazon ecosystems to produce biomass, an average of 500-700 tons per hectare. As informed by Manuela Carneiro da Cunha and Mauro Almeida from data offered by Susana Hecht and Steve Schwartzmann (1988),

Recent comparative studies quantified the difference in costs and benefits between cattle raising, agriculture and extractivism in the state of Acre, taking into account the cost of soil recovery and excluding the global effects of burning or losses of germplasm. Without discounting the price of soil recovery for a 15 year project, extractivism generates average annual profits five times higher than agriculture and 15 times above livestock. If we add the cost for soil recovery [...] in 20 years the results are negative in the amount of US\$28,000-55,000 for agriculture and US\$ 60,000-100,000 for livestock. Extractivism shows gains of US\$ 30,460-50,000 (Da Cunha \& Almeida, 2000, p. 332)

Thus, agro-extrativism appears as the best sustainable production strategy for the Amazon region for its efficient negentropic management of energy with practices embodied in the reinvented identities and territorialities of the Seringueiros and other peoples of the Amazon ecosystems.

\subsection{The R-existence of Black populations}

Afro-descendent populations are among the most important cultural identities and political actors emerging in the field of political ecology. In Brazil, the Constitution of 1988 recognized the rights of Black communities to their territories. These rights are the result of struggles for $r$-existence, after these populations, trying to flee from the regimes of slavery to which they were subjected during the XVIII and XIX centuries, were forced to find refuge in the regions of more difficult access (mountains, rugged terrains, floodplains and savannas) that happen to be territories of rich biodiversity.

An emblematic case is that of the Black populations of the Colombian Pacific, whose rights to their territories (palenques) and their cultures were recognized by the Constitution of 1991 (Escobar, 2008). The Process of Black Communities (PCN) of the Colombian Pacific emerged from a project for the conservation of biodiversity as a result of the environmental policies derived from the Rio- 92 process. By claiming their rights to participate in this project, these communities initiated an emancipation process leading to the reconstruction of their identities and the struggle for their cultural rights for autonomy and reappropriation of their territory. As expressed by these emergent environmental actors, their fundamental principles for emancipation and political organization are: 
1. The reaffirmation of identity (the right to being black) [...] from the perspective of our cultural logic and lifeworld in all of its social, economic and political dimensions [...] 2. The right to the territory (the space for being) as a vital space and a necessary condition for the recreation and development of our cultural vision [...] in harmony with nature [...]. 3. Autonomy (the right to the exercise of being/identity) [...]. 4. Construction of an autonomous perspective for the future [...] an autonomous vision of economic and social development based on our culture and traditional forms of production and social organization [...]. 5. Declaration of solidarity with the struggles for rights of black populations throughout the world $[\ldots]$ for alternative life projects [...] (Escobar, 2008, p. 223).

Hernan Cortés, leader of the PCN movement, expresses the imaginaries that are in the roots of their cultural identity, confronting the hegemonic powers of modernity, debating their own existence and opening the perspectives for their possible futures. His word intertwines in the textures of interculturality and the hybridizing of being within the context of biodiversity, culture and sustainability:

The relation between afro-descendent peoples and nature is determined by ancestral mandates, that grasp criteria preserved from our African ancestors, others appropriated from indigenous cultures, and criteria that were defined in the process of social and cultural reconstruction in the territories where liberty had been conquered. Our death people are never gone, they remain in the trees, in the brooks, in the rivers, in fire, in rain, on the shore [...] The ancestral mandate: we all are a bigfamily, grants us a profound respect to all other beings in nature that as living beings, the trees, the earth, the animals, water... have rights. The dynamics of population, mobility, territorial occupation, and use and management practices of biodiversity depend on the conception that the trilogy territory, culture, biodiversity is an integral, indivisible whole; the territory is defined as a space for being and biodiversity as that which allow us to remain [...] the afro-descendent peoples assume nature as a biocultural system where social organization, productive practices, religiosity, spirituality and the word [...] determine our living well (vivir bien) (Cortés, in Leff, Ed., 2002, p. 217-218)
These emergent "hybrid" identities are constructed not only as strategies of resistance in opposition to other identities and hegemonic powers; they are not mere fragmented political identities; they are the renewal of cultural being that is constituted as a we for living in the commons: in new life-territories. The struggles for emancipation are struggles for the r-existence of cultural beings, for their re-appropriation of nature and coexistence of diverse cultural beings in a global world ruled by politics of difference and ethics of otherness. They are not only claims to improve economic and ecological distribution, but disputes of meaning for the construction of alternative life-worlds: of other possible worlds emerging from the imaginaries, through the words and practices of the people.

Thus, the emancipation process of black Afrodescendents, as that of indigenous and peasant peoples are legitimizing the right to cultural difference and to common identities; to "other" knowledge, savoirs and practices that confront the truth of positivistic science and modern rationality. These struggles for environmental justice are decolonizing positive law and the power-knowledge devices that have been legalized and institutionalized by the hegemonic dominant order, to emancipate other cultural beings and social actors in the construction of a sustainable future (Leff, 2012).

\subsection{The R-existence of babassu coconut breaker women}

Babassu (Orbygnia phalerata) is a palm tree that predominates in floodplains near the valleys of the rivers and in small hills associated to other type of vegetation of the hot and humid tropics in the states of Pará, Maranhão, Tocantins, Mato Grosso and, outside of the conventional Amazonia, in Piauí. It encompasses altogether 14.5 million hectares of land. Traditionally this was not a natural resource of commercial interest. On the contrary, it was intimately linked to cultural practices for the reproduction of peasant families, particularly in the valley of Mearim in Maranhão. Babassu was a resource for free exploitation. Its utilization fulfilled the need of landlords to reproduce the peasant's labor force. From 1980 on, a strong social movement started to develop 
through associations that lead to the constitution in the 90s of the Interstate Movement of Babassu Coconut Breaker women (MIQCB) that includes near 300.000 families of agro-extractivist workers.

In more recent years, with capitalist expansion and greater access to these lands, many landowners started to prohibit the extraction of babassu arguing invasion of land, affecting cultural practices consecrated by traditional customs. Conflicts emerged from the different interests related with the exploitation of the palm tree. In their struggle for land and the defense of babassu groves, the babassu growers claim their natural means of production and their mode of living as a way of overcoming poverty and constructing sustainable livelihoods. These conflicts ended up aligning social groups in encountered positions, leading to the affirmation of collective identities that, given the importance of women and of infant labor, launched the coconut breaker women to the political-cultural scene in a struggle against the devastation of babassu groves (babaçuais) and to put an end to the prohibition of collecting it, that is, to "free babassu". In the II Interstate Meeting of Babassu Coconut Breakers, held in Teresina, PI, in 1993, these women demanded:

1. Dis-appropriation of all areas in conflict in the region of babaçuais; 2. Free coconut: access to babassu palms for women and children dedicated to its extraction, including private properties that do not fulfill a social function; 3. Put an end to the cutting of babassu palm trees; 4. Abolish all violence against rural workers in babassu groves zones; 5 . Apply resources for the development of cooperatives; 6 . Implement settlements in already dis-appropriated areas and extractive reserves; 7 . Comply with the Statute of Children and Adolescents in Rural Zones; 8. Measures to ensure the compliance with the Decree of Extractive Reserves (Porto-Gonçalves, 2001a).

Thus, the Law for Free Babassu (Lei do Babaçu Livre) was promoted having been approved in different municipalities, as in the Lago do Junco, Lago dos Rodrigues, Esperantinópolis, São Luís Gonzaga and Imperatriz, in Maranhão; Axixá, Praia Norte e Buriti, in the State of Tocantins; and in São Domingos do Araguaia, in the State of Pará. By this law everybody can enter any property to collect coconuts for their needs, without interfering with the activities of the owner. The law prohibits cutting down the palm trees and the use of chemical products. As a result, the income of these populations have increased as they diversified the selfuse and commercialization of babassu products, not only as oil, soap and mesocarp for flour.

\subsection{Fishing reserves of Amazon River dwellers}

Fishing is one of the main traditional activities developed in the largest hydrographic basin in the world: the Amazon; it is a practice inscribed in a polyvalent mode of living of the population that provides an important source of food. The riverside caboclo is one of the most characteristic Amazonian figures. Their current practices reflect the diverse cultures of indigenous peoples, Portuguese immigrants, migrants from the Northeast and black populations that converge and hybridize in their identities and practices. By dwelling in the floodplains in the margins of the rivers, they developed a complex environmental knowledge in their coexistence with rivers and forests. These Amazonians have been characterized as polyvalent fishermen to differentiate them from the univalent fishermen that live basically from commercial fishing. In their vision and practices of nature, forests and rivers are interconnected and interdependent; their modes of production and living are intertwined with the Amazon ecosystems in their agricultural, extractive and fishing practices.

These polyvalent fishermen have survived colonial domination through their environmentally sound productive rationalities. Generally they live in small villages and places located in the river margins-igarapés, furos and paranás - managed with their traditional techniques through a rich tradition in the construction of boats and houses adapted to ecosystems. They divide their time in cyclical activities related to terrestrial ecosystems such as small hatcheries, agricultural tillage, hunting, collecting and extracting during the year; they work their own or rented land, raise cattle, cultivate juta, hunt, collect seeds, fruits, resins and wild fibers; they produce coal, they mill cassava flour and fish, first for self-consumption and then for commercialization. The riverside popula- 
tions of extractive fishermen-farmers have managed for years their fragile, complex and productive ecosystems without any support from public policies.

These riverside communities are now being involved in territorial conflicts confronting the present process of appropriation of natural resources by capitalistic enterprises, resulting in overfishing that threatens the sustainability of their livelihoods. As Lourdes Furtado explains,

in the view of the inhabitants of the lake banks that depend on their ichthyological resources, this pressure over resources produces an impact as fish become scarce and the fishermen have difficulties to get a good catch, sufficient to fulfill their needs for food and for selling a small surplus to acquire other goods; this threatens the sustainability of the stock of fishing resources and the food chain that allows the renewal of the necessary resources for life [...] generating expectations and internal tensions that many times lead to conflicts that manifest in different actions, from simple warnings to the "invader", the removal and burning of malhadeira nets, taking away fishing boats and canoes, up to the prohibition of fishing in the lakes (Lourdes Furtado, 2002, p. 38).

Furthermore, David Mcgrath points out the fact that:

As a response to this pressure, some riverside communities are taking possession of local lakes, establishing rules to limit the capture of fish and to guarantee fishing productivity [...] As a form of local control of fishing resources, the community management of lakes can be a promising strategy for the sustainable development of the floodplain (várzea) resources (Mcgrath, 1993).

Important parallelisms and differences exist between the Lake Reserve and Extractive Reserves:

The Lake Reserve is a form of land use very similar to the Extractive Reserve. Both of them are efforts of traditional populations to guarantee their access to resources that are the basis of their local family economies, preserving their livelihoods. If both of them search to preserve natural ecosystems and are based in traditional forms of occupation, there also exist important differences between them due to the characteristics of the main resources [...] In the case of the Lake Reserve the mobility of the fishing resources makes it unviable to create individual territories. All fishermen exploit the same population of fish and in general each fisher's production affects the productivity of others. In spite of the fact that in the land around the lake there are individual owners, the lake is considered a "common good" for collective management, involving all fishermen of the community. In this context, the economic viability of the reserve depends not only on the rules established, but also on the quality of the community organization, especially on the participation of the fishermen in the fishing agreements defined by the community (Mcgrath, 1993, p. 39).

From the dialogue of knowledge established between those populations of fishermen and conventional technicians, new proposals emerge seeking to overcome the colonial-modern paradigm that separates nature and culture. A good example is that of the "ban-wage". The ban or prohibition is an instrument of protection of a species when limitations to fishing are set during the periods of reproduction. With the application of the ban-wage, fishermen receive a minimum salary throughout that period, while at the same time they learn and develop a series of activities to diversify their sources of food.

The ban-wage proposal represents an innovation in the economic and juridical system to overcome the dichotomy between nature and society. Thus, labor and nature are revalued to avoid the overexploitation of labor and nature by the traditional theory of value and the prevalent economic system that pays only the seasonal labor time. The ban-wage considers the time necessary for the reproduction of the natural resources and of the worker. By internalizing the ecological and cultural conditions for the sustainable productivity of biomass in a determinate ecosystem, that is, by considering the ecological and cultural value of the process of production, and not only its present market price, society as a collectivity assigns itself the responsibility to preserve nature - the river, the shore, the lake, the fish-as well as the fishermen's culture.

This reordering of production leads to revalue the fishermen's traditional knowledge, but moreover to consider him (or her) a citizen of rights -and the bearer of such rights-, including the rights to inhabit their ter- 
ritories and to construct their economy according to their own cultural values. Thus, environmental rationality opens new perspectives for the construction of sustainable societies through the innovative actions of emergent social actors that institute new social practices, culturally embodied and ecologically embedded in their territories.

\subsection{Experiences of community forestry in México}

The experiences of community forestry in México offer another good example of cultural management of biodiverse territories and forest products by peasant and indigenous communities oriented towards the social construction of sustainable local economies (Merino \& Segura, 2002). Different from the Chilean experience of large monoculture forest plantations -that is developing in vast extensions in Brazil for tradable forest products like cellulose-, community forestry is based in the management of the biodiversity of natural forests. The forests coverage in Mexico is of 127.6 million hectares, of which 63.5 million hectares are tropical forests and rainforests. Mexico is the country with the largest certified area of communal land under social forestry management. Eighty per cent of these forests are under social ownership (ejidos or communal property). Following Bray (2007), there were 164 such forest enterprises. Only in the State of Oaxaca, about 150 forest communities practice community forestry management in 650,000 hectares (Boege, 2008). Until 2005, there were 26 certified communities and ejidos (Anta, 2005) with an extension of 587,143 hectares (Alatorre, 2003). In general, these forests are located in mountain landscapes that contain in their different ecological floors some of the largest terrestrial biodiversity; thus, the management of the forest common goods implies in the conservation of genetics, species and ecosystems diversity, and of their ecological and environmental services (for an extensive bibliography on community forestry in Mexico, see Cossio et al., 2006).

Similar to the experience of extractive reserves in Brazil, social forestry in Mexico is the result of an intense struggle for the re-appropriation of natural resources, previously in the hands of the State or private concessionaires. The taking of lands, sawmills and transport units, as well as the legal struggles against concession- aires, is part the process that leads to the reinvention of the community's identity for innovative management and new institutional frameworks to construct culturally and ecologically based sustainable forestry practices.

The more successful experiences on sustainable forest management are those where communities have undergone a process of re-appropriation and reconstruction of their traditional knowledge and practices. In Quintana Roo, for example, tappers (gatherers of chicle resin from sapodilla, Manilkara zapota) that came in the first half of the XIX Century from the State of Veracruz learned from the Mayas the names of local vegetation, wildlife behavior, traditional medicine, interpretations of the myths on annual rain cycles and the complex classification and uses of soils. After the cancellation of forest concessions at the beginning of the decade in 1890 , the local peasantry appropriated the techniques that for 25 years had been in use by a large state enterprise to harvest 600 thousand cubic meters of cedar and mahogany in the natural forest.

Forest inventories are an important requirement to maintain a constant harvest of commercial wood, without undermining the resource. The first forest inventories generated a collective intellectual appropriation process. The forest technicians that worked in the zone were trainees in forestry educated for the temperate areas. Maya knowledge and wisdom of the tropical forest corresponded to another productive logic. The community assembly decided that the majority of its associates should participate in the inventories, opening paths, measuring, classifying and learning sampling techniques. Thus a horizontal exchange of knowledge took place including the names of trees and soils following the Maya knowledge and the assimilation by the community of the resources from its territory.

Peasant forestry enterprises constantly innovate their productive strategies in a dialogue of knowledge between researchers, technicians and the local people involved. In fact, this peasant forestry strategy involves a process of re-appropriation and blending of local knowledge with other technical knowledge. In this context, a constant negotiation is generated between the technical knowledge of forest engineers and traditional practices of forest regulation.

With the experiences of communal forestry in Mexico, as in other cases in Petén, Guatemala, the prin- 
ciples of community autonomy are being validated as a basis for an alternative project for peasant and indigenous peoples' communities and ejidos. These experiences contribute to define alternative paths for the construction of local economies based on the self-management of sustainable territories by indigenous and peasant communities. They are important laboratories to test and construct new forms of cultural and social occupation of the territory from the potentials of biodiversity and cultural diversity. These new strategies of territorial ordering and natural forest management from multiple cultural and productive approaches are incorporating new agro-ecological and agroforestry approaches, multiple use of ecological floors and soil management techniques, the conservation of endangered species and sustainable management of wildlife, with new rules for the collective access and use of common resources for the sustainable management of complex forest and bio diverse ecosystems based on the principles of environmental rationality (Leff et al., 2002).

\section{Social actors for the construction of sustainable territories}

The community agroforestry experiences in Mexico, as well as the experiences of the Extractive Reserves in Brazil are examples of the invention of new productive rationalities for the sustainable appropriation of nature in the conflictive terrain of political ecology where these territorialities are being confronted by techno-economic power strategies and contesting interests. Thus, the indigenous-peasant population of Los Chimalapas located between the States of Oaxaca and Chiapas, has been struggling to gain control over an area of 600.000 hectares of tropical rainforest in the Southern Mexico, to create a Peasant Biodiversity Reserve (Reserva Campesina de Biodiversidad de Los Chimalapas). The invention of this concept parallels that of the seringueiros in Brazil. Both of them stress the ecological (biodiversity) and sociological (peasantry) basis of these strategies that define the innovative and radical quality of these alternative paradigms of sustainability. Both the Peasant Reserves of Biodiversity and the Extractive Reserves go beyond the concept of Environmental Conservation
Units, where the population is excluded. Here the local population becomes the main protagonist in the management of natural resources.

Today, in the context of economic globalization and the geopolitics of sustainable development, new territorialities are being configured: it is no longer a struggle of national states to expand its limits, and not only the tensions emerging from the emancipation of indigenous peoples and other cultural groups within national states for the constitution of plurinational states. The deepening of capital globalization, as well as emerging democratization processes are opening new ways of emancipation and the construction of sustainable territories based on legitimization of cultural and environmental rights that offer the conditions for other social actors to enter the political arena, encountering the National State and its internal colonialism as well as the hegemonic economic world system. In the field of political ecology a diversity of new political subjects emerge. New voices are expressing environmental demands, as those in the Peoples Summit of Climate Change and the Rights of Mother Earth celebrated in Cochabamba, Bolivia, in April 2010. It was precisely in Cochabamba where previously in the year 2000, the Water War (Guerra del Agua) involved peasants, indigenous peoples, environmentalists and urban movements, to chase away Bechtel, the multinational enterprise involved in the privatization of water, to be followed latter by the Gas War in 2003, and the raising to power of the first president elected as the result of an indigenous and peasant movement, in 2005.

Peasant and indigenous peoples movements - the "campesindios" (Bartra, 2008) and the "indigenato" (Ribeiro, 1980) - are undertaking a relevant role, especially after 1992, to liberate from a long history of colonization and exclusion, of cultural subjugation, deterritorialization and destruction of their patrimony of natural resources. Their emancipation from that dominating process involves the politicization of their ancestral territories. Their demands for territorialization go beyond traditional struggles for land. These struggles incorporate their emergent rights to re-appropriate their patrimony of natural resources and to reconstruct their territories in the perspectives opened by sustainability for the destiny of humanity facing the environmental crisis and of life in the planet; against the processes of de-territorialization/ 
expropriation and for the defense of their cultures and of cultural diversity. Their struggles involve the defense of their natural conditions of existence under which they develop their cultural values and the meanings of their social practices. Thus, the triad territory-territorialityterritorialization emerges in the core of political ecology.

In the crossroads of the contradictions of the colonial-modern world system and the resulting environmental crisis, the different social classes and ethnic groups revive their historic resistance against the expropriation of their territories, their lands and ecological conditions of existence, reconfiguring the epistemic-political debate facing the increasing environmental risks and the dilemmas on sustainability. These emergent social movements introduce the social and cultural question in the field of political ecology. The expression of Chico Mendes "There can be no defense of the forest without the peoples of the forest" synthesizes the social struggles in different places in the world: the Chipko movement in India, the conflict in Los Chimalapas in the tropical forest in the states of Oaxaca and Chiapas in Mexico, the Process of Black Communities of the afro-Colombians of the Pacific, the Articulation of Peoples of the Savannas (cerrados) in Brazil; the fishing agreements (acordos de pesca), the "closed season wages" (salário defeso), the marine reserves, and other forms of territorial configurations proposed by socio-environmental movements. In different geographic contexts culture is being politicized in the territorial question through the struggles over the appropriation of nature (Porto-Gonçalves, 2004).

Even in countries where indigenous populations are relatively small in demographic terms, they deploy a large cultural and linguistic diversity, as is the case of Brazil, where they represent only $0.4 \%$ of total population, but speak 188 different languages, five times more than in Bolivia where they speak 32 languages and the population corresponds to $62 \%$ of total population. This opens a new ethic-political dilemma. Beyond the rights of existence of all peoples and their cultures, these populations occupy areas rich in biodiversity and ecological potentialities that are being threatened by regional integration projects such as the Initiative for the Integration of the Regional Infrastructure of South America (IIRSA) launched in 2000 with the participation of the 12 countries of South America which form the Union of South American Nations, supported by the Corporación Andina de Fomento (CAF), the InterAmerican Development Bank (IDB) and the River Plate Basin Financial Development Fund (Fonplata) to link South America's economies through new transportation, energy, and telecommunications projects (to integrate highway networks, river ways, hydroelectric dams and telecommunications links throughout the continent) to allow greater trade for the South American community of nations; or the contested and failed Mesoamerican Integration and Development Project -the Puebla-Panama Plan-launched in 2001 to promote the regional integration and development of the nine southern states of Mexico with all of Central America and Colombia.

These projects are opening these areas to regional infrastructure projects as well as to transnational enterprises for the exploitation of minerals, land and water resources for agro-business and new commodities exportation. These territories become strategic areas for alternative and confronting rationalities and interests, fronts of dispute for the appropriation of their natural resources.

Indigenous peoples and peasants are taking new stands in the political ecology debate, escaping the political traps of multicultural postmodernity that maintains essentialism and stimulates xenophobia. Their struggles focus on decolonization, inter-culturality, and dialogue of knowledge. They construct their new rights for cultural being that entail their re-identification with nature, the re-appropriation of their history and their patrimony of natural resources, reinventing their life territories and reimagining their future. In reconstructing their territories, they redefine their own notions of time and space, different from those of the hegemonic Eurocentric thinking. Peoples like the Aymara and Quechuas have their own cosmogonies of the Pacha, a universe ordered in spatial-temporal categories characteristic of the Andean cultural rationality (Estermann, 2006).

The emancipation of peoples in the re-appropriation of nature is starting to be reflected in important transformations of the State at the national level. Thus Bolivia has been re-constituted as a Plurinational state. Ecuador was the first country to introduce the rights of nature in its Constitution, followed by Bolivia. Also in Ecuador, following the initiative of the indigenouspeasant-environmental movement, the government 
of Rafael Correa is negotiating a project to maintain underground the oil in the National Yasuny Park, in the Andean-Amazonian foothills, by collecting half of the value that could be obtained with its exploitation. Breaking apart the compensation mechanisms such as the REDD and other economic transaction instruments in the Clean Development Mechanism -that assign to poor countries the role of absorbing the surplus emissions of greenhouse effect gases while the rich countries keep expanding their ecological footprint-, here the intention is to stop extracting oil -with the risks of polluting the natural ecosystems-in the benefit of the local indigenous peoples and of the planet as a whole, and to apply its revenue to clean energy and socio-environmental sustainable projects (Vogel, 2009).

These emergent social processes anchored in the legitimization of new cultural and environmental rights, are challenging the juridical system for the construction of the collective rights to the commons. This no longer implies broadening the scope of the hegemonic law system based on the principles of individual rights and private property as a means to deal and solve the "tragedy of the commons" (Hardin, 1968), denying the customs in common (Thompson, 1991) and customary rights of the communities. These peoples claim intellectual property rights of another order (Posey \& Dutfield, 1996; Posey, 2004). The original, traditional and communal knowledge of these communities is a common and collective patrimony that demands a new juridical rationality that recognizes their communal and communitarian character, avoiding reducing them to the principles of positivistic science and law that are contrary to their cultural values and foundations.

These socio-environmental struggles are redefining the power relations in the field of political ecology for the social re-appropriation of nature. As they gain legitimacy, they are incorporated to legal arrangements and public policies. There have been important formal developments in the recognition of the emergent indigenous peoples' rights in countries like Brazil with its Constitution of 1988, Colombia with Laws 70 and 121 in its Constitution of 1991, and the Organic Law of Indigenous Peoples in Venezuela. However they face enormous difficulties in their implementation and enforcement not only due to the factual powers that dispute their territorialities -as in the case of the Colombian Pacific-, but also to the persistence of a nationalist, productivist and development ideology so encrusted in the power structures of the world-system and the National State, that continues ignoring the rights of cultural being claimed historically by the original peoples to live and produce within nature according to their traditional knowledge and practices. This is leading to increasing conflicts and tension between the interests derived from global economic rationality and the construction of an environmental rationality in the transition to sustainability.

In Brazil, the struggles of the Seringueiros that established new relations between the State and civil society have been under high stress to complete its purposes and extend it to other communities because of the deflation of the State in the recent years to neoliberal hegemony. The Extractive Reserve was the first modern proposal to break apart from the paradigm of management of nature reduced to conservation units that separates nature and culture. In the Extractive Reserves -as previously in all traditional practices and cultural co-evolution with nature, populations' knowledge is a condition sine qua non of conservation. Thus, a new paradigm was territorialized based on the culture of the people and in the access to land as territory. The same principle applies to the demarcation of afro-Brazilians quilombos, whose vast territories were reinvented by the maroons to free themselves from slavery after having been ignored by the dominating culture and kept willingly invisible as a survival strategy. Today, these territories represent new opportunities for those people to reinvent and regain control over their ways of existence while becoming an obstacle to new fronts of expansion of capital.

The bottom question that surfaces in the midst of these territorial struggles is a substantive issue that has remained invisible in the mainstream environmental debate. What is at stake is the social re-appropriation of nature and the purpose of building sustainable societies founded in the diverse ecological and cultural conditions of the peoples of the Earth, the construction of territories of difference (Escobar, 2008). The exploitation of nature is not only a condition for the domination of some men over others, of rich countries over poor countries, of a 
hegemonic rationality over subjugated cultures. Human beings as well as life in the planet have become hostages of a struggle to appropriate limited nature by confronting rationalities. This is expressed in conflicts of territorialities where alternative cultural and civilizing projects encounter themselves for the appropriation of the natural conditions of human existence. These are the profound implications of the present social struggles for re-appropriation of nature, triggered today by the confrontation of a globalized unsustainable economic world-system and the emancipation of populations with strong territorial bonds, of many original and indigenous peoples who have managed to survive; of peasants, maroons, and landless peoples that having been de-territorialized, are claiming their rights to re-territorialization.

The territorial struggles for sustainability in the field of political ecology go beyond the old debate on development/underdevelopment trapped in the ideal of unlimited growth and progress. The theoretical-political debate on the destiny of humanity and of the planet are now posed in terms of the alternatives for a sustainable future: from the doubtful possibilities of techno-economic solutions to the entropic death of the planet triggered by unsustainable economic growth, to an environmental rationality based on the negentropic conditions for life in this living planet, guided by new horizons of meaning, as those expressed today by the "living well" (Suma Kawsay or Suma Qamaña) of the people of the Earth (Huanacuni, 2010).

These socio-environmental questions emerge today in the shaky ground of economic globalization, environmental crisis and climate change where the Latin American geography is confronting one of the most violent expropriation processes in the whole history. The prevailing economic developmental regime promotes the construction of highways, hydroelectric dams and polluting extractive mineral enterprises; the expansion of the agricultural frontier to new transgenic latifundia and monoculture forest plantations; deforestation and the reduction of the rich ecological and biodiversity potentials of Latin America to function as carbon sinks, with the purpose of absorbing the surplus emissions of greenhouse gases of the more polluting industrialized countries and emergent economies in what is euphemistically called "green economy". These are the domineer- ing ongoing transformation processes generated by the compliance of governments with the new geopolitics of "sustainable development". Thus, Latin America and the Third World countries face a new wave of territorial conflicts, more complex and at a larger scale than the ones that were triggered by the "green revolution" and the construction of hydroelectric dams that displaced peoples from their territories and altered profoundly the ecological processes of the region.

The renewal of exploitative colonial-modern rationality today geared by the growing capitalization of nature is generating new territorial conflicts. A good example of the political tensions and the confronting processes of territorialization between capitalistic and environmental rationalities is the case of the recent struggle over TIPNIS - Tierra Indigena del Parque Nacional Isiboro Securé - located in the Andean-Amazonian foothills of Bolivia. The defense of this "cultural ecosystem" has mobilized indigenous peoples against the construction of a highway under the IIRSA project planned to cut through the middle of their territories to open a way to the Pacific for Brazil. Likewise, the invasion of mining enterprises in Latin America is generating all sorts of resistance movements. One example is that of the National Confederation of those Affected by Mining (Confederación Nacional de los Afectados por la Minería, CONACAMI) in 2009 in Peru that was involved in one of the most violent conflicts of the last years in Bagua - where dozens of people, including military, died in the confrontation of indigenous peoples against mining industries that intended to expand over the Andean-Amazonian confines where these people live -, followed by a more recent conflict in Cajamarca, in 2011. In Brazil tense relations prevail with indigenous and peasant movements that are resisting the construction of dams in Belo Monte in the Xingu river, as well as in Jirau and Santo Antonio in the Madeira river, and in the São Francisco river.

\section{The social construction of environmental rationality}

Recent experiences of socio-environmental movements in Latin America, as elsewhere in Asia and Africa, 
are showing the capacity of the local people not only to resist the hegemonic economic, instrumental and utilitarian reason through which capitalism penetrates their geographic-socio-cultural life territories, but also to create alternative visions and new paths to sustainability from their cultural rationalities, reinventing their identities, their productive practices and their livelihoods. They evidence also that traditional populations are holders of knowledge and practices that are interwoven with the ecological conditions for a sustainable management of their environments. These successful experiences are legitimating new human rights to the territory and opening innovative perspectives for sustainability driven by social movements for a cultural re-appropriation of nature.

While the globalization process is penetrating every territory and ecosystem, every culture and individual, with its unsustainable techno-economic rationality, these emergent socio-environmental movements are constructing an alternative globalization from the potentialities of their ecosystems, their cultural identities and their local autonomies, sustained and articulated by an alternative environmental rationality. Beyond the purpose of facing the environmental crisis by assigning an economic value to nature and culture, environmental rationality guides the construction of a sustainable global civilization by integrating a diversity of organizational processes oriented by the negentropic principle of life and cultural signification of nature. This process encompasses the reconfiguration of cultural identities and the emergence of new social actors capable of innovating new productive processes based in the ecological potentials of nature and the cultural creativity of the peoples of the Earth.

Traditional knowledge, oppressed and dominated by scientific, economic and technological rationality of modernity, is being reconstructed in emergent local settings, hybridizing in conflicting ways traditional practices with modern scientific and technological knowledge. Traditional societies and local economies do not only produce use and exchange values; they generate also "meaningful use values" which reflects the complex relation of the natural and the symbolic order in socio-economic and political relations of production. Under this rationality, nature is not submitted to the strategies of sustainable development and guided by the dominant economic rationality. Environmental rational- ity deconstructs economic rationality by constructing an eco-technological-cultural paradigm of production founded on the principle of negentropic productivity (Leff, 1995). The conditions of life and the inventions of diverse cultures, registered in the imaginaries and practices of the peoples reemerge today under processes of re-signification, reaffirmation and updating of their cultural identities in the re-territorialization of their life-worlds.

While modern rationality tends to dissolve geographic references and cultural meanings, space and place are being "reinvented" from the core of the emergent cultural identities to embody and to root the conditions for sustainable societies in new life territories. This change of rationality goes beyond the objective of grounding the global economic rationality locally with the intention of establishing a balance between ecological conservation and economic growth. The construction of sustainability rooted on principles of environmental rationality is the embodiment and embeddedness of new material conditions, cultural values and symbolic meanings. Place becomes the locus for rooting diversity, where nature and culture coexist in the complexity of natural processes and diverse cultural beings that construct their territorialities in different space-time settings. The concreteness of sustainability is defined in the encounter and convergence of different matrixes of cultural rationalities; in a dialogue of knowledge that constitutes different cultural beings in their relation to their imaginaries, their savoirs and practices, in their inhabited environments (Leff, 2004, Cap. 7).

Anchored and driven by these socio-environmental movements, crossed by tense conflicts in the complex matrix of rationality of modernity -the hegemonic homogeneity of instrumental economic rationality-, the social construction of environmental rationality is emerging from the confluence of new ideas, projects and rights, where old concepts -territory, autonomy, selfmanagement, local knowledge- are being re-signified, reconfiguring new territorial identities and new productive strategies.

New socio-environmental movements are thus emerging in the field of political ecology searching to construct a sustainable future with social and environmental justice, with cultural and territorial diversity, with 
other horizons of meaning. From peoples' imaginaries of sustainability, cultural rights for the re-appropriation of nature is being created and legitimized, reconfiguring a new political agenda based in the cultural and natural patrimony of the peoples, in the reinvention of their identities and their life territories.

\section{Conclusions}

The environmental crisis irrupted in the world in the 60 s raising new epistemic and political challenges. Among the diverse issues debated in the conflictive field of political ecology, a radical question characterizes the socio-environmental movements in Latin America: the definition of new paths for constructing sustainable societies based on their ecological potentials and cultural identities. It is a struggle for an alternative social rationality through the social appropriation of their natural patrimony and the reinvention of their territories.

Through conquest and colonization, the original peoples experienced a long history of exploitation and de-territorialization. After 500 years of resistance they

\section{References}

Abramovay, R. Reduzir a desigualdade entre os indivíduos para combater o aquecimento global. Boletim da Sociedade Brasileira de Economia Ecológica, special edition 23/24, 12-15, 2010.

Ab'Saber, A. N. Províncias geológicas e domínios morfoclimáticos no Brasil. Geomorfologia, 20, 1-25, 1970.

Alatorre, E. El proceso de certificación forestal en México. Dirección de Certificación Forestal. Consejo Civil Mexicano para la Silvicultura Sostenible en México, 2003.

Argueta, A.; Vázquez, M. C. G. Atlas de las plantas de la medicina tradicional mexicana. 3 vol. México: Instituto Nacional Indigenista, 1994.

Barbados Declaration. International Work Group for Indigenous Affairs/World Council of Churches, 1971.

Bartra, A. El hombre de hierro. Los límites sociales y naturales del capital. Mexico City: Universidad Autónoma de la Ciudad de México, 2008. have started a process of emancipation and decolonization, a struggle for the re-appropriation of their historical patrimony of natural resources and reinvention of their cultural identities. Countering the strategies of "sustainable development", these emergent social movements are opening new horizons of meaning for human history based on their social imaginaries for sustainability. The principles of these emergent cultural and environmental rights embrace a political ethics that involves a critique of current trends of development, political domination and nature exploitation. It is a claim to r-existence, to build their sustainable life-worlds based on their worldviews and forms of cognition, their cultural ways of inhabiting the planet and their own territories, establishing new relations with nature and with other human beings: a spiritual and material balance with the cosmos, their ecological environment and their social relations. These emergent social actors -indigenous peoples, peasants and afro-descendants- place cultural diversity in the center of the political ecology debate. A new thinking and practice is mobilizing the social construction of an environmental rationality that gives its identity to Latin American political ecology.

Boege, E. El patrimonio biocultural de los pueblos indigenas de México. Hacia la conservación in situ de la biodiversidad y agrobiodiversidad en los territorios indígenas. México: INAH/Comisión Nacional para el Desarrollo de los Pueblos Indígenas, 2008.

Campos, N. Terras de uso comum. São Paulo, PhD Thesis (Programa de Pós-graduação em Geografia) - Universidade de São Paulo, São Paulo, 2000.

Carlson, R. The silent Spring. Boston: Houghton Mifflin, 1962.

Cardona, G. R. La floresta di piume. Manuale di etnoscienzia. Roma: Editore Laterza, 1986.

Castro, J. de. Subdesenvolvimento: causa primeira da poluição. In: Castro, J. de. Fome: um tema proibido - últimos escritos de Josué de Castro. Rio de Janeiro: Civilização Brasileira, 2003. p. 135-137.

Ceceña, A. E. La guerra infinita. Buenos Aires: CLACSO, 2002. 
Cornetta, A. Mecanismo de desenvolvimento limpo e conflitos locais. In: Anais do XIII Encontro de Geógrafos de América Latina, San José, Costa Rica, 2011.

Cossio, R. E.; Bray, D. B.; Bult, S.; Merino, L. Bibliografía anotada del manejo comunitario de los bosques en México, con bibliografía adicional sobre los bosques de México en general (Working Paper No. 2). LACC Working Paper Series, 2006. $<$ http://digitalcommons.fiu.edu/laccwps/11>.

Da Cunha, M. C.; Almeida, M. Indigenous People, Traditional People and Conservation in the Amazon. Daedalus, 129(2), 315-338, 2000.

De Gortari, E. La ciencia en la historia de México. México: Fondo de Cultura Económica, 1963.

Enzensberger, H. M. A critique of political ecology. New Left Review, 84, 3-31, 1974.

Erlich, P. The population bomb. New York: Ballantine Books, 1968.

Escobar, A. Territories of difference. Place, movements, life, redes. Durham/London: Duke University Press, 2008.

Esterman, J. La filosofia andina. Quito: Ed. Abya Yala, 2006.

Fanon, F. The wretched of the Earth. New York: Grove, 2004.

Fals Borda, O. La ciencia del pueblo, en Investigación Participativa y Praxis Rural. Nuevos conceptos en educación y desarrollo comunal. Lima: Perú Editorial Mosca Azul, 1981.

Fals Borda, O. Ciencia propia y colonialismo intelectual. Los nuevos rumbos. 3. ed. Bogotá: Carlos Valencia Editores, 1987.

Friends of the Earth. Overconsumption? Our use of the world's natural resources. 2006. In: $<\mathrm{http}$ ://www.foeeurope.org/ publications/2009/Overconsumption_Sep09.pdf $>$.

Furtado, C. O mito do desenvolvimento econômico. São Paulo: Paz e Terra, 1974.

Furtado, L. Pescadores do Rio Amazonas. Um estudo antropológico da pesca ribeirinha numa área amazônica. Brasília: MCT-CNPq-Museu Emilio Goeldi, 2002.

Georgescu-Roegen, N. The entropy law and the economic process. Cambridge, Mass.: Harvard University Press, 1971.

González Casanova, P. Internal colonialism and national development. Studies in Comparative International Development, 1(4), 27-37, 1965.

Hardin, G. The tragedy of the commons. Science, 162, 12431248, 1968.
Harvey, D. The new imperialism. Oxford: Oxford University Press, 2003.

Haesbaert, R. O mito da desterritorialização: do "fim dos territórios" à multiterritorialidade. Rio de Janeiro: Bertrand Brasil, 2004.

Haesbaert, R. A global sense of place and multi-territoriality: notes for dialogue from a 'peripheral' point of view. In: Featherstone, D.; Painter, J. Spatial Politics: Essays for Doreen Massey, Chichester: John Wiley and Sons, 2013.

Hecht, S. B.; Schwartzman, S. The Good, the Bad and the Ugly: Extraction, colonist Agriculture and Livestock in Comparative Economic Perspective. Los Angeles: Westing Papers, UCLA, 1988.

Huanacuni, F. Vivir bien/Buen vivir: Filosofía, políticas, estrategias y experiencias regionales. La Paz: Convenio Andrés Bello/Instituto Internacional de Integración, 2010.

International Indian Treaty Council. 2000. In: $<\mathrm{http}: / / w w w$. treatycouncil.org/>.

Lander, E. (Ed.) La colonialidad del saber. Buenos Aires: CLACSO/UNESCO [a compilation of the principal Latin American thinkers on the coloniality of knowledge], 2000.

Leff, E. Green production. Towards an environmental rationality. New York: Guilford, 1995.

Leff, E. La geopolítica de la biodiversidad y el desarrollo sustentable: economización del mundo, racionalidad ambiental y reapropiación social de la naturaleza. In: Ceceña, A. E.; Sader, E. La Guerra Infinita. Hegemonía y terror mundial. Buenos Aires: CLACSO-ASDI, 2002. p. 191-216.

Leff, E. (Ed.). Ética, vida, sustentabilidad. México: PNUMA, 2002. (Serie Pensamiento Ambiental Latinoamericano N. 5).

Leff, E. Racionalidad ambiental: la apropiación social de la naturaleza. México: Siglo XXI Editores, 2004.

Leff, E. Imaginarios sociales y sustentabilidad. Cultura y representaciones sociales, 9, 42-121, 2010.

Leff, E. Political ecology. A Latin American perspective. Desenvolvimento e Meio Ambiente, 35, 29-64, 2015.

Leff, E.; Argueta, A.; Boege, E.; Porto-Gonçalves, C. W. Más allá del desarrollo sostenible. La construcción de una racionalidad ambiental para la sustentabilidad. Una visión desde América Latina. In: Leff, E.; Ezcurra, E.; Pisanty, I.; Romero, P. (Eds.). La transición hacia el desarrollo sustentable. Perspectivas de América Latina y el Caribe. México: PNUMA/ INE-SEMARNAT/UAM, 2002. p. 479-578. 
López-Austin, A.; López-Luján, L. Mexico's indigenous past. Norman: University of Oklahoma Press, 2001.

Mariátegui, J. C. Seven interpretive essays on Peruvian reality. Texas Pan American Series, Austin: University of Texas Press, 1971.

Marini, R. M.; dos Santos, T. (Coords.). El pensamiento social latinoamericano en el siglo XX. Caracas: UNESCO, 1999. 2 Vols.

Mignolo, W. Local histories/global designs: coloniality, subaltern knowledges, and border thinking. Princeton: Princeton University Press, 2000.

Mignolo, W. Modernity and decoloniality. Oxford Bibliographies, 2011.

Martinez Alier, J. The merchandising of biodiversity. CNS, 7(1), 37-54, 1996.

Meadows, D. H.; Meadows, D. L.; Randers, J.; Behrens III, W.W. The Limits to Growth. New York: Universe Books, 1972.

Merino, L.; Segura, G. El manejo de los recursos forestales en México, 1992-2002. Procesos, tendencias y políticas públicas. In: Leff, E.; Ezcurra, E.; Pisanty, I.; Romero, P. (Ed.). La Transición Hacia el Desarrollo Sustentable. Perspectivas de América Latina y el Caribe. México: PNUMA/INE-SEMARNAT/UAM, 2002. p. 237-256.

Moscovici, S. La société contre nature; Paris: Union Générale d'Édition, 1972. (Collection 10/18).

Murra, J. The Economic Organization of the Inca State. Chicago: University of Chicago, 1956.

Packard, V. The waste makers. Brooklyn: Ig Publishing, 1960.

PNUMA. Manifesto for life. For an ethic for sustainability. 2002. <www.rolac.unep.mx>.

Polanyi, K. The Great Transformation: The Political and Economic Origins of Our Time. Boston: Beacon Press, 1944.

Porto-Gonçalves, C. W. Geo-grafias: movimientos sociales, nuevas territorialidades y sustentabilidad. México: Siglo XXI, 2001.

Porto-Gonçalves, C. W. Amazônia, Amazônias. São Paulo: Contexto, 2001a.

Porto-Gonçalves, C. W. O latifúndio genético e a r-existência indígeno-camponesa. Geographia, 4(8), 7-30, 2002.

Porto-Gonçalves, C. W. Geografando nos varadouros do mun$d o$ : da territorialidade seringalista à territorialidade seringueira. Brasília: IBAMA, 2004.
Porto-Gonçalves, C. W. A globalização da natureza e a natureza da globalização. Rio de Janeiro: Civilização Brasileira, 2006.

Porto-Gonçalves, C. W. Em defesa dos organismos laboratorialmente modificados: em busca da precisão conceitual. 2007. Disponível em: <http://www.geopolitica.ws/article/ em-defesa-dosorganismos-laboratorialmente-modificados/ $>$.

Porto-Gonçalves, C. W. Territorialidades y lucha por el territorio en América Latina. Geografía de los movimientos sociales en América Latina. Caracas: IVIC, 2010.

Posey, D. A. Indigenous knowledge and ethics: a Darrell Posey reader. New York: Routledge, 2004.

Posey, D. A.; Dutfield, G. Beyond intellectual property: toward traditional resource rights for indigenous peoples and local communities. Ottawa: IDRC, 1996.

Quijano, A. Colonialidad del poder, eurocentrismo y América Latina. In: Lander, E. (Ed.). La colonialidad del saber: eurocentrismo y ciencias sociales. Perspectivas latinoamericanas. Buenos Aires: Clacso/Unesco, 2000.

Raffestin, C. Pour une géographie du pouvoir. Paris: Librairies Techniques, 1980.

Ribeiro, D. Indigenato e campesinato. Revista de Cultura Vozes, 73, LXXIII-8, 5-10, 1980.

Ribeiro, B. G. Amazônia urgente: cinco séculos de história e ecologia. Belo Horizonte: Itatiaia/INEP-MEC/CNPq/Vitae, 1992.

Sack, R. Human territoriality: its theory and history. Cambridge: Cambridge University Press, 1985.

Santos, M. A natureza do espaço. Técnica e tempo; razão e emoção. São Paulo: Hucitec, 1996.

Tapia, L. La invención del núcleo comum: ciudadanía y gobierno multisocietal. La Paz, Bolívia: Ed. Muela del Diablo, 2009.

Thompson, E. Customs in common: studies in traditional popular culture. London: Merlin Press, 1991.

Toledo, V. M.; Caballero, J.; Argueta, A. El uso múltiple de la selva basado en el conocimiento tradicional. Biótica, 3, 85-101, 1978.

Uhl, C.; Nepstad, D.; Silva, J. M. C.; Vieira, I. C. G. Restauração da floresta em pastagens degradadas. Ciência Hoje, 13, 23-31, 1991.

Vogel, J. H. The Economics of the Yasuní Initiative: Climate Change as if Thermodynamics Mattered. London/New York/ Delhi: Anthem Press, 2009. 